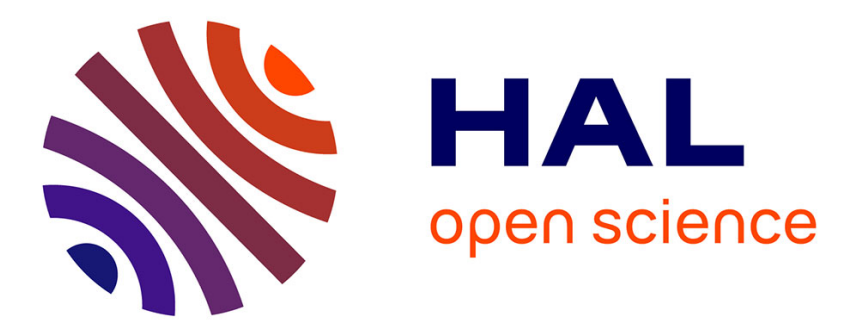

\title{
Changes in the cell wall network during the thermal dehydration of alfalfa stems
}

M. Hamm, Philippe Debeire, Bernard B. Monties, Brigitte Chabbert

\section{To cite this version:}

M. Hamm, Philippe Debeire, Bernard B. Monties, Brigitte Chabbert. Changes in the cell wall network during the thermal dehydration of alfalfa stems. Journal of Agricultural and Food Chemistry, 2002, 50 (7), pp.1897-1903. 10.1021/fj011294q . hal-02680613

\section{HAL Id: hal-02680613 https://hal.inrae.fr/hal-02680613}

Submitted on 31 May 2020

HAL is a multi-disciplinary open access archive for the deposit and dissemination of scientific research documents, whether they are published or not. The documents may come from teaching and research institutions in France or abroad, or from public or private research centers.
L'archive ouverte pluridisciplinaire HAL, est destinée au dépôt et à la diffusion de documents scientifiques de niveau recherche, publiés ou non, émanant des établissements d'enseignement et de recherche français ou étrangers, des laboratoires publics ou privés. 


\title{
Changes in the Cell Wall Network during the Thermal Dehydration of Alfalfa Stems
}

\author{
M. Hamm, P. Debeire, B. Monties, and B. Chabbert* \\ Institut National de la Recherche Agronomique, UMR FARE-614, Centre de Recherches \\ Agronomiques, 2 Esplanade Roland Garros, B.P. 224, 51686 Reims Cedex 02, France
}

\begin{abstract}
The effects of heat treatments used to dry alfalfa stems were investigated. Heating at 70 or $100{ }^{\circ} \mathrm{C}$ caused no major change in the cell wall composition, but xylanase had lower activity on the cell wall of heated material and the amount of xylose released varied with the temperature used. Chemical fractionation of cell wall carbohydrates showed that the main changes occurring during stem dehydration concerned pectic polymers and probably hemicelluloses. There was less material soluble in ammonium oxalate from alfalfa heated at $100^{\circ} \mathrm{C}$ than from fresh alfalfa. The results suggest that heat processing causes some changes in the cell wall network. Environmental scanning electron microscopy was used to examine fully hydrated tissues at high resolution. There was cell distortion without disruption of cell walls as water was lost.
\end{abstract}

KEYWORDS: Cell wall; processing; pectin; Medicago sativa; endo- $\beta-(1 \rightarrow 4)-x y l a n a s e$

\section{INTRODUCTION}

Heating is one of the most widely used methods of preserving food. Many industrial processes use wet heating, such as blanching or canning, prior to drying. Forages are widely produced around the world; however, different processes are used depending on the country. Thus, foodstuffs can be preserved by air-drying in the field, but artificial dehydration of alfalfa is a very common industrial process in France. This thermal dehydration involves a two-step drying process that converts fresh alfalfa into dry pellets. The chopped raw material is gently heated at $70{ }^{\circ} \mathrm{C}$ prior to the main dehydration step, which involves heating to a temperature of $600{ }^{\circ} \mathrm{C}$ for a short time ( $\sim 15 \mathrm{~min})$. This lowers the moisture content of the alfalfa from nearly 80 to $15 \%$. Because the drying process does not aim for humidity values of $<15 \%$, the rate of water diffusion from the sample is high and the alfalfa temperature should range over $70-80{ }^{\circ} \mathrm{C}$ during the high-temperature process (1). The nutritive quality of the fresh forage (fibers, vitamins, and proteins) is thus preserved $(2,3)$. Proximate analysis of cell walls indicates that industrial drying has no effect upon forage fibers $(4-6)$.

Plant cell walls are composites of cellulose microfibrils imbedded in a hemicellulose-pectin matrix. Lignin also accumulates in the thick walls of vascular tissues. These polymers are held together by various kinds of cross-linkages to give a true cell wall network. The complexity of the cell wall and the range of plant processes may well result in many very complex changes in its structure and properties. These effects may be relevant to the physical properties of the plant material and are not yet well understood (7). Most research on the cell wall has,

* Corresponding author (telephone 00333267735 97; fax 0033326 7735 99; e-mail chabbert@ reims.inra.fr). until now, focused on the structure of the cell wall of food treated by moist heating (sterilization or blanching) $(8-10)$. It has shown modifications of the structure of pectin polysaccharides such as thermal condensations involving $\beta$-elimination reactions $(7,11)$. Most of these studies have been done on poorly lignified dietary fibers (fruits and vegetables), which have mainly pectin-rich primary walls. The possible modifications of lignified cell walls during forage processing have not been studied extensively, apart from their overall composition. Nonwood fibers from renewable sources such as forage crops have drawn increased interest for nonfood potential use. Development of such agrofibers would gain from a better insight on the effect of processing on forage cell wall. Particularly, the behavior of pectins under alfalfa processing is of interest because alfalfa cell walls are pectin-rich, and the thermal processing of foods has already been shown to affect pectins. Studies about the effect of forage processing (or storage) on cell walls are mainly based on data from Van Soest fractionation, which gives an indication of the proportion of the main cell wall components. However, this method has limitations as some pectin substances are lost in the detergent procedure (12). We have investigated some of the changes that occur in the cell walls (composition and organization) during alfalfa drying on industrial and laboratory scales. The present research involves the main findings from laboratory-scale drying of alfalfa stems. The focus has been on the chemical changes that occur in the cell wall during heating in a forced-air oven at 70 or $100{ }^{\circ} \mathrm{C}$ with respect to the expected temperature in the industrially processed alfalfa. The overall composition, in terms of the main polysaccharides (neutral and acidic sugars) and lignin, of the cell walls of fresh and dry alfalfa stems was measured. Changes in cell wall polymer accessibility could reflect chemical changes resulting in the reorganization of interpolymer bonds. Changes in the 
lignin-polysaccharides network of forage caused by heat treatment were thus investigated by chemical $(13,14)$ and enzymatic (endoxylanase) (15) fractionation of cell walls. The effect of water loss on stem-tissue integrity using an environmental scanning electron microscope (ESEM) (16) was also examined.

\section{MATERIALS AND METHODS}

Plant Materials and Heating Conditions. Alfalfa (Medicago sativa L.) cv. Mercedes was sown at Reims, France, in 1998 and harvested at $1 / 10$ blooming stage during the spring of 2000 . Plants were cut $\sim 5 \mathrm{~cm}$ above ground level. The leaves were discarded, and the stems were cut into $3 \mathrm{~cm}$ fragments and dried in a forced-air oven at $70 \pm 3{ }^{\circ} \mathrm{C}$ for $3.5 \mathrm{~h}$ or at $100 \pm 4{ }^{\circ} \mathrm{C}$ for $1.5 \mathrm{~h}$. The fresh and dried materials were ground in a mechanical mortar (Retsch) in ethanol $(80 \% \mathrm{v} / \mathrm{v})$ at $20{ }^{\circ} \mathrm{C}$ and the residues treated with ethanol $(80 \% \mathrm{v} / \mathrm{v})$ at $40{ }^{\circ} \mathrm{C}(15$ min, 4 times) and with water at $40{ }^{\circ} \mathrm{C}(15 \mathrm{~min}, 3$ times $)$ to produce a cell wall residue (CWR). Fresh stems were also collected and directly used in microscopy studies.

Sugar Analysis. Neutral Sugars. The neutral sugar content of the CWR was determined according to the method of Blakeney et al. (17). CWRs $(10 \mathrm{mg})$ were hydrolyzed using a modified Seaman hydrolysis (18) with $72 \% \mathrm{H}_{2} \mathrm{SO}_{4}(\mathrm{w} / \mathrm{v})(125 \mu \mathrm{L})$ for $2 \mathrm{~h}$ at $20^{\circ} \mathrm{C}$, followed by a second hydrolysis with $2 \mathrm{M} \mathrm{H}_{2} \mathrm{SO}_{4}$ at $100{ }^{\circ} \mathrm{C}$ for $2 \mathrm{~h}$. Soluble fractions of CWR were hydrolyzed without the $72 \%$ (w/v) $\mathrm{H}_{2} \mathrm{SO}_{4}$ step. Neutral sugars were quantified as their alditol acetates by gas chromatography using the standard procedure of Englyst and Cummings (19) using inositol as an internal standard. Alditol acetates were separated on an SP2380 column (Supelco; $30 \mathrm{~m} \times 0.25 \mathrm{~mm}$ internal diameter; 0.20 $\mu \mathrm{m}$ film) with a temperature gradient of $230-250{ }^{\circ} \mathrm{C}$ at $2{ }^{\circ} \mathrm{C} / \mathrm{min}$. The carrier gas was helium ( 1 bar), and detection was performed by flame ionization.

Total Uronic Acids. Samples were hydrolyzed with sulfuric acid as above, and total uronic acids were determined by using the $m$-phenylphenol method (20) with galacturonic (CWR and isolated pectin fractions) or glucuronic acid (isolated hemicellulose fractions).

Reducing Sugars. Reducing sugars released by enzymatic hydrolysis of CWR were quantified spectrophotometrically using ferricyanide reduction $(21)$.

Lignin Analysis. The lignin content was determined spectrophotometrically using the acetyl bromide reagent $(22,23)$ and spruce milled wood lignin as reference. This reference contained $<5 \%$ neutral sugar as determined by Kurek et al. (24).

The lignin monomer composition was determined by thioacidolysis. A sample of CWR (12 mg) was heated in $10 \mathrm{~mL}$ of dioxane/ethanethiol $(9: 1, \mathrm{v} / \mathrm{v})$ containing $0.2 \mathrm{M}$ boron trifluoride etherate for $4 \mathrm{~h}$ at $100{ }^{\circ} \mathrm{C}$ (25). Monomer products were analyzed by capillary column gas chromatography as trimethylsilyl derivatives. They were separated on an SPB1 column (Supelco; $30 \mathrm{~m} \times 0.3 \mathrm{~mm} ; 0.25 \mu \mathrm{m}$ film thickness) using a temperature gradient of $160-280{ }^{\circ} \mathrm{C}$ at $2{ }^{\circ} \mathrm{C} / \mathrm{min}$. Helium was the carrier gas at 0.6 bar, detection was done by flame ionization, and tetracosane was the internal standard.

Xylanase-Mediated Fractionation of Cell Walls. Enzyme. Endo$\beta$-(1 $\rightarrow 4)$-xylanase (EC 3.2.1.8) was produced by a thermophilic Bacillus sp. and purified to homogeneity as previously described $(26,27)$. The purified enzyme had an activity of $400 \mathrm{UI} / \mathrm{mL}$, a molecular mass of $20.7 \mathrm{kDa}$, and a $\mathrm{p} I$ of 7.7 .

Enzymatic Hydrolysis. CWRs were swollen in deionized water at $60{ }^{\circ} \mathrm{C}$ for $16 \mathrm{~h}$ to release water-soluble sugars. CWRs $(2 \% \mathrm{w} / \mathrm{v})$ were hydrolyzed with endoxylanase $(14 \mathrm{UI} / \mathrm{mL})$ at $60{ }^{\circ} \mathrm{C}$ for $24 \mathrm{~h}$ with constant stirring. Samples were withdrawn periodically, placed in a boiling water bath (IKA Labortechnik) for $5 \mathrm{~min}$, and centrifuged (Beckman, Avanti 30) at $10500 \mathrm{rpm}$ for $5 \mathrm{~min}$. The supernatants were further analyzed for reducing sugar. In addition, the amount of xylose in the released carbohydrate was determined after acid hydrolysis of the supernatant when the reaction was completed.

Chemical Fractionation of Cell Walls. CWRs from fresh and 100 ${ }^{\circ} \mathrm{C}$-dried alfalfa were extracted to remove pectin polysaccharides and hemicellulose polysaccharides. CWRs $(600 \mathrm{mg})$ were first extracted with $100 \mathrm{~mL}$ of distilled water and continuous stirring in a water bath at $80{ }^{\circ} \mathrm{C}$ for $1 \mathrm{~h}$. The water-insoluble residue was recovered by filtration on a Büchner funnel equipped with a Whatman No. 40 filter paper and heated with $100 \mathrm{~mL} 0.5 \%$ ammonium oxalate with continuous stirring in a water bath at $80{ }^{\circ} \mathrm{C}$ for $1 \mathrm{~h}$. The resulting residue was recovered as above. The filtrate was dialyzed $(\mathrm{MW}=3500)$ against running water for $18 \mathrm{~h}$ and then against four changes of deionized water for $2 \mathrm{~h}$. Two extractions with ammonium oxalate were performed to remove pectin polysaccharides $(13,28)$. The oxalate-insoluble material was treated twice with $50 \mathrm{~mL}$ of $0.05 \mathrm{~N}$ hydrochloric acid in a water bath at $85^{\circ} \mathrm{C}$ for $30 \mathrm{~min}$. The residue was recovered as before and the extraction repeated. Dilute hydrochloric acid extracts some cell wall pectins (29).

The pectin-free residues were treated with increasing concentrations of sodium hydroxide to extract the hemicellulose polysaccharides (14, 30). The residues from $\mathrm{HCl}$ extraction were suspended in $100 \mathrm{~mL}$ of $1 \mathrm{~N} \mathrm{NaOH}$ containing $3 \mathrm{mg} / \mathrm{mL} \mathrm{NaBH}_{4}$ for $3 \mathrm{~h}$ at $20{ }^{\circ} \mathrm{C}$ with continuous stirring, filtered on a Büchner funnel, and washed with deionized water. They were then extracted with $4 \mathrm{~N} \mathrm{NaOH}$ as above. The resulting final residue was neutralized with water and freeze-dried (Christ). The alkali extracts and the washes were combined, neutralized with $6 \mathrm{~N}$ hydrochloric acid, and dialyzed as above. The filtrates were reduced to $10 \mathrm{~mL}$ in a rotary evaporator (Heidolph 2000) and stored at $-20{ }^{\circ} \mathrm{C}$. Soluble extracts were analyzed for neutral sugars and uronic acids.

ESEM. ESEM allows the observation of hydrated tissues, in contrast to the usual scanning electronic microscopy, for which samples must be dried. The moisture and pressure in the specimen chamber can be changed for dynamic studies. The environmental scanning electron microscope (Philips ESEM-FEG XL30) combines a differential pumping system with a gaseous secondary electron detector to produce good resolution images of fully hydrated material (16).

Hand-cut sections of fresh alfalfa stems $(100 \mu \mathrm{m})$ were obtained from the middle part of the stem. Sections were placed on a Peltier cooler, chilled block to keep the sample temperature at 0 and $3{ }^{\circ} \mathrm{C}$. The relative humidity was $100 \%$ for a water vapor pressure of 10 Torr. Dehydration of two sections obtained from three distinct stems was thus examined.

Statistics. Experiments were run in duplicate, analytical data varying by $<5 \%$ were obtained, and a Student's one-way $t$ test was used with confidence limits of 5 or $10 \%$.

\section{RESULTS AND DISCUSSION}

The initial moisture content of the fresh alfalfa stems samples was $81 \%$. They were heated to a final water content of nearly $15 \%$, which is the value obtained by industrial processing. The water content of the samples was checked during drying. The rate of drying changed with the temperature; over $3 \mathrm{~h}$ was required for drying at $70{ }^{\circ} \mathrm{C}$ and only $1.5 \mathrm{~h}$ for drying at 100 ${ }^{\circ} \mathrm{C}$. Differences in the drying temperatures and rate of water loss could have distinct effects on the cell walls.

Cell Wall Composition. The cell wall residues remaining after the ethanol and water extractions could not be quantified due to the procedure used in cell wall isolation. Indeed, grinding using the mechanical mortar was convenient for directly removing the extractives, but some material loss could not be avoided. However, estimation of the proportion of alfalfa CWR did not result in significant differences $(p<0.05)$ between fresh and industrially dried alfalfa (Hamm et al., unpublished observations). The cell walls of alfalfa stems were mainly structural polysaccharides and lignin. They accounted for nearly $90 \%$ of the CWR from fresh and 70 or $100{ }^{\circ} \mathrm{C}$-dried alfalfa stems (Table 1). Almost 6\% was total protein in the CWRs (total nitrogen $\times 6.25$ ) (data not shown).

Neutral sugars and uronic acids accounted for $\sim 70 \%$ of the CWR (Table 1). There was no significant change in the carbohydrate content after the experimental treatments. Glucose was the main sugar, mainly from cellulose, the main cell wall component. Xylose, the second most abundant monosaccharide, 
Table 1. Cell Wall Composition of Fresh, $70^{\circ} \mathrm{C}$-Dried, or 100 ${ }^{\circ} \mathrm{C}$-Dried Alfalfa Stems ${ }^{a}$

\begin{tabular}{lccc}
\hline & fresh & $70^{\circ} \mathrm{C}$ & $100^{\circ} \mathrm{C}$ \\
\hline acetyl bromide lignin & 17.3 & $15.9^{\mathrm{a}}$ & 17.6 \\
guaiacyl & 722 & 737 & 750 \\
syringyl & 417 & 442 & 392 \\
total S + G & 1139 & 1179 & 1142 \\
ratio S/G & 0.58 & 0.60 & 0.52 \\
uronic acids & 14.2 & 13.5 & 13.4 \\
total neutral sugar & 56.3 & 55.0 & $52.9^{\mathrm{b}}$ \\
rhamnose & 0.9 & 0.9 & 0.9 \\
fucose & 0.3 & 0.3 & 0.3 \\
arabinose & 4.8 & 4.4 & 4.6 \\
xylose & 18.8 & 18.2 & 20.2 \\
mannose & 3.5 & 3.3 & 3.4 \\
galactose & 3.5 & 3.2 & 3.2 \\
glucose & 68.2 & 69.7 & 67.4
\end{tabular}

${ }^{a}$ Lignin, uronic acids, and total neutral sugar contents expressed as percent of total CWR. Yields of lignin monomer products recovered by thioacidolysis expressed in micromoles per gram of lignin. Individual neutral sugars expressed as percent of total sugar content. Values followed by a letter are significantly different from other values within the same row.

indicated the presence of xylan-type hemicelluloses such as glucuronoxylans and xyloglucans usually found in dicotyledons (31). The total amount of (Glu $+\mathrm{Xyl}$ ) accounted for $90 \%$ of the total neutral sugars, which is characteristic of mature alfalfa (32). Overall, fresh and dried stems had similar CWR carbohydrate compositions (as neutral sugars), indicating that ovendrying at 70 and $100{ }^{\circ} \mathrm{C}$ had no major effect on the repartition of the main structural carbohydrates (Table 1).

The proportions of uronic acids in the stems of the various alfalfa CWR were similar. These values are consistent with previous findings for mature alfalfa stem CWRs $(30,31)$.

Lignin represented $17 \%$ of the CWRs from both fresh and dry stems. Thioacidolysis released thioethylated derivatives of the guaiacyl and syringyl residues specifically involved in the labile-ether-linked lignin structure (25). Thioacidolysis of CWR from fresh and dried alfalfa resulted in similar yields of etherlinked monomers. Total yields $(\mathrm{S}+\mathrm{G})$ were $\sim 1150 \mu \mathrm{mol} / \mathrm{g}$ of lignin, reflecting the proportion of labile-ether-linked lignin structures, reported as the uncondensed lignin fraction. This fraction was roughly $20 \%$ of the whole lignin polymer, in agreement with previous findings in alfalfa stem lignin. The $\mathrm{S} / \mathrm{G}$ molar ratio indicated the lignin type usually found in mature alfalfa (14).

The chemical data for alfalfa CWRs were consistent with the cell wall features of mature alfalfa; this stage corresponds to harvesting alfalfa having nearly $10 \%$ in bloom. The stem is mainly xylem with thick secondary cell walls containing cellulose, lignin, and xylan. The proportion of xylose to arabinose increases with the formation of syringyl lignin type deposits $(14,33)$.

Thus, these compositional data agreed with previous data based on proximate analysis of the cell walls, despite the fact that information on pectins was not available. Present findings indicate that the pectins of the CWR undergo no noticeable degradation during heat treatment, in contrast to moist thermal food processing which leads to pectin degradation $(7,11)$.

Xylanase Fractionation of Alfalfa Cell Walls. The accessibility of in situ hemicelluloses of fresh and dried alfalfa stems was evaluated using xylanase hydrolysis $(14 \mathrm{UI} / \mathrm{mL})$ for $24 \mathrm{~h}$. The enzyme hydrolyzes xylans by disrupting the $(1-4)$ glycosidic bonds between two xylose residues but does not cleave the glycosidic bond between xylose residues where one of the

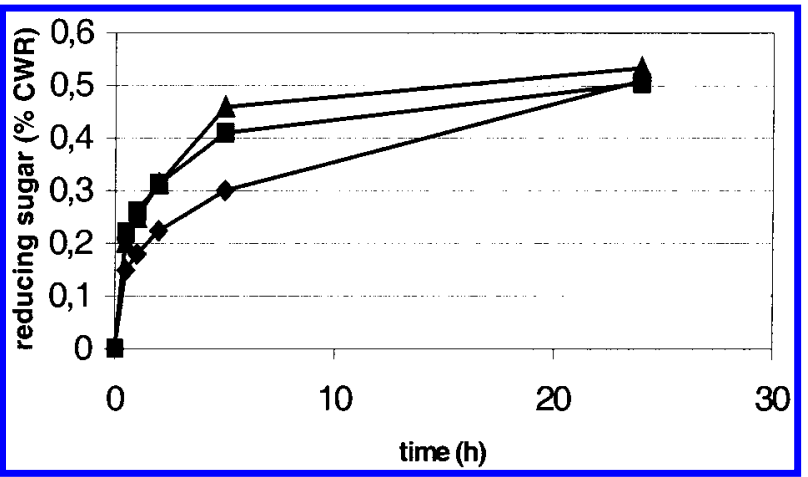

Figure 1. Reducing-sugar content of carbohydrates released during endoxylanase hydrolysis of fresh $(\bullet)$ and $70^{\circ} \mathrm{C}$-dried $(\boldsymbol{\square})$ or $100^{\circ} \mathrm{C}$ dried $(\mathbf{\Delta})$ alfalfa cell walls.

Table 2. Xylose Content of Carbohydrates Released after $24 \mathrm{~h}$ of Endoxylanase $(14 \mathrm{UI} / \mathrm{mL})$ Hydrolysis of Fresh and 70 or $100{ }^{\circ} \mathrm{C}$-Dried Alfalfa Cell Walls (Expressed as Percent of Initial Xylose)

\begin{tabular}{lr}
\hline cell wall residue & $\%$ xylose \\
\hline fresh stems & $11.3 \pm 0.1$ \\
$70^{\circ} \mathrm{C}$-dried stems & $9.4 \pm 0.4$ \\
$100^{\circ} \mathrm{C}$-dried stems & $7.6 \pm 0.2$ \\
\hline
\end{tabular}

residues is substituted. The course of hydrolysis was followed by the determination of reducing sugar and was the same for all the types of alfalfa stems (Figure 1). Hydrolysis was rapid during the first $5 \mathrm{~h}$ and then slowed to reach a plateau. However, less xylose was found in the enzyme products after $24 \mathrm{~h}$ of hydrolysis of CWR from $70{ }^{\circ} \mathrm{C}$-dried alfalfa than from fresh material (Table 2). The amount of xylose present in carbohydrates released from alfalfa dried at $100{ }^{\circ} \mathrm{C}$ was even lower (30\% less). Thus, heat treatment of alfalfa made the in situ xylans less accessible to xylanase hydrolysis.

The xylose content of enzyme-released carbohydrates accounted for a low proportion of initial xylose content of alfalfa walls. The limited xylanase hydrolysis was due to the way the enzyme acts; it cannot cleave xylose chains near branch points, so that glucuronoxylan in lignified secondary walls, as in alfalfa stems, could hamper hydrolysis. In addition, the cell wall network and environment of hemicelluloses could cause differences in accessibility. The presence of lignin could implicate steric hindrance, as suggested by studies on the enzymatic degradation of wheat straw (34) or the partial binding of enzyme to lignin $(15,35)$. There were differences between the CWRs from fresh and dried samples, despite the rather poor enzymatic degradation. The changes in xylan accessibility, in particular, can be regarded as due to heating of the cell wall network; that is, the cross-linkage pattern between such cell wall components as lignin/hemicellulose may be altered.

Pure enzymes can thus be efficient tools for detecting subtle changes in the cell wall. In contrast, the combined action of nonspecific mixed-enzyme preparations may minimize differences in cell walls, especially for very minor changes in the cell wall network, as shown here for heated alfalfa.

Chemical Fractionation of Alfalfa Cell Walls. Chemical fractionation was used to estimate the extractibility of the structural carbohydrates from CWRs to better understand the changes in the cell wall network after heating. Sequential fractionation of alfalfa CWR was not used to isolate homogeneous polysaccharides groups. Pectin polysaccharides were extracted with hot water, ammonium oxalate, and dilute hydrochloric acid. Ammonium oxalate released $\mathrm{Ca}^{2+}$-complexed 
Table 3. Total Neutral Sugar Content of the Fractions Solubilized by Chemical Extractiona

\begin{tabular}{lccccc}
\hline & \multicolumn{2}{c}{ fresh stems } & & \multicolumn{2}{c}{$100^{\circ} \mathrm{C}$-dried stems } \\
\cline { 2 - 3 } & $\begin{array}{c}\text { \% initial } \\
\text { CWR }\end{array}$ & $\begin{array}{c}\text { \% initial } \\
\text { total sugar }\end{array}$ & & $\begin{array}{c}\text { \% initial } \\
\text { CWR }\end{array}$ & $\begin{array}{c}\text { \% initial } \\
\text { total sugar }\end{array}$ \\
\hline initial & 56.34 & 100 & & 52.94 & 100 \\
$\mathrm{H}_{2} \mathrm{O}$ & 1.47 & 2.61 & & $1.00^{\mathrm{a}}$ & $1.89^{\mathrm{a}}$ \\
oxalate & 0.73 & 1.30 & & 0.66 & 1.25 \\
$\mathrm{HCl}$ & 1.99 & 3.53 & & 1.87 & 3.53 \\
$1 \mathrm{~N} \mathrm{NaOH}$ & 7.54 & 13.38 & & $7.33^{\mathrm{b}}$ & $13.84^{\mathrm{b}}$ \\
$4 \mathrm{~N} \mathrm{NaOH}$ & 3.38 & 5.99 & & 3.94 & 7.45 \\
total extracted & 15.11 & 26.81 & & 14.80 & 27.96 \\
& & & & &
\end{tabular}

${ }^{a}$ Results expressed as a percent of initial CWR or initial total sugar. Values for dried stems followed by a letter are significantly different from values for fresh stems $(a, p<0.05 ; b, p<0.1)$.

Table 4. Total Uronic Acid Content of the Fractions Solubilized by Chemical Extractiona

\begin{tabular}{lccccc}
\hline & \multicolumn{2}{c}{ fresh stems } & & \multicolumn{2}{c}{$100^{\circ} \mathrm{C}$-dried stems } \\
\cline { 2 - 3 } \cline { 5 - 6 } & $\begin{array}{c}\text { \% initial } \\
\text { CWR }\end{array}$ & $\begin{array}{c}\text { \% initial } \\
\text { UA }\end{array}$ & & $\begin{array}{c}\text { \% initial } \\
\text { CWR }\end{array}$ & $\begin{array}{c}\text { \% initial } \\
\text { UA }\end{array}$ \\
\hline initial & 14.19 & 100 & & 13.38 & 100 \\
& & & & $0.30^{\mathrm{a}}$ & $2.26^{\mathrm{a}}$ \\
$\mathrm{H}_{2} \mathrm{O}$ & 0.44 & 3.11 & & $2.02^{\mathrm{a}}$ & $15.06^{\mathrm{a}}$ \\
oxalate & 2.57 & 18.10 & & 0.65 & 4.90 \\
$\mathrm{HCl}$ & 0.74 & 5.18 & & 1.23 & 9.17 \\
$1 \mathrm{~N} \mathrm{NaOH}$ & 1.19 & 8.37 & & $0.40^{\mathrm{b}}$ & $3.00^{\mathrm{b}}$ \\
$4 \mathrm{~N} \mathrm{NaOH}$ & 0.28 & 1.95 & & 4.60 & 34.39 \\
total extracted & 5.22 & 36.71 & & &
\end{tabular}

${ }^{a}$ Results expressed as a percent of initial CWR or initial uronic acid (UA). Values for dried stems followed by a letter are significantly different from values for fresh stems $(a, p<0.05 ; b, p<0.1)$.

polymers. Most of the oxalate-insoluble pectins were subsequently extracted with dilute $\mathrm{HCl}$, presumably by hydrolysis of weak ester cross-links. The resulting residues were treated with sodium hydroxide to extract hemicelluloses. Various amounts of heterogeneous polysaccharide fractions were released from alfalfa CWR, as shown in Tables $\mathbf{3}$ and $\mathbf{4}$ and Figure 2.

Extracts of Pectin Polymers. Water-soluble polymers of dried alfalfa stems contained significantly less uronic acid than did extracts of fresh stems (Table 4). The amounts of watersoluble polysaccharide containing neutral sugars followed the same trend (Table 3). However, the relative compositions of the polysaccharides released from fresh and dried stems, as neutral sugars, were similar (Figure 2). Water-extracted neutral and acid pectins [polygalacturonic acid (PGA), arabinans, arabinogalactans, and rhamnogalactans] and some xyloglucans are present in primary cell walls $(14,36)$.

The polysaccharides extracted by ammonium oxalate contained a large proportion of uronic acid (Table 4), which accounted for $80 \%$ of the total soluble sugar. Galacturonic acid was the major uronosyl residue in these isolated fractions (28), with almost exclusively polygalacturonic acid. The acid pectin in dried stems was less accessible than that in fresh stems. In addition, the neutral sugar composition of oxalate-extractable polysaccharides from oven-dried stems contained less arabinose than extracts of fresh stems (Figure 2). Nevertheless, the same proportions (10\%) of arabinose, with respect to the initial CWR, were released from fresh and $100{ }^{\circ} \mathrm{C}$-dried stems. Thus, the same major neutral sugars were extracted from both the fresh and dried residues.

Hydrochloric acid released similar amounts of neutral and acid-containing polysaccharides from the fresh and dried residues (Tables 3 and 4), and their neutral sugar compositions were quite similar (Figure 2). Indeed, the proportions of arabinose, the major monomer sugar in the fraction, were not significantly different. However, $48 \%$ of the initial arabinose was soluble from dried alfalfa compared with only $42 \%$ from
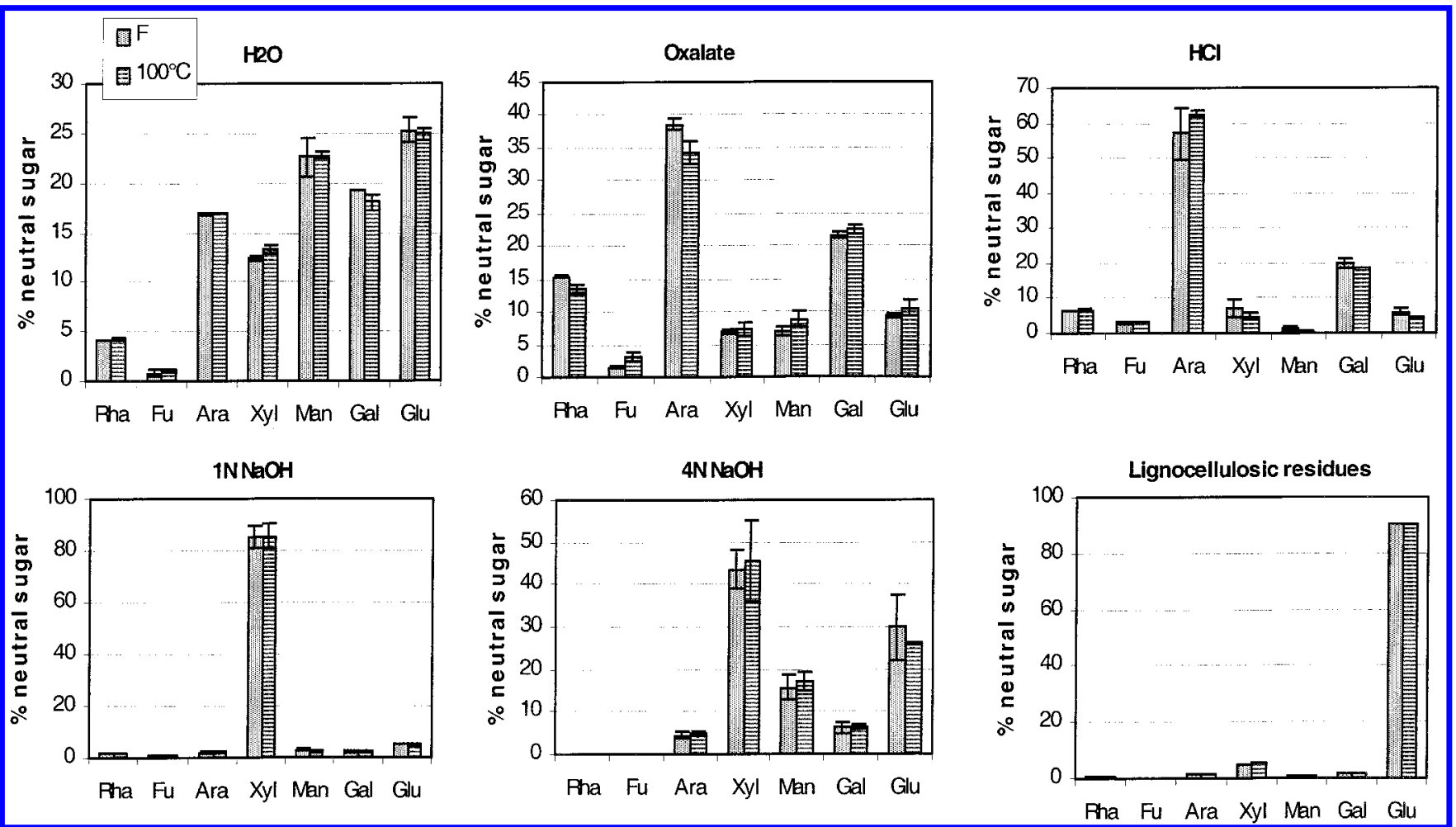

Figure 2. Relative composition in neutral sugar of the soluble fractions (expressed as a percent of total releasing neutral sugars) and of the final lignocellulosic residues (expressed as a percent of total sugar content). 


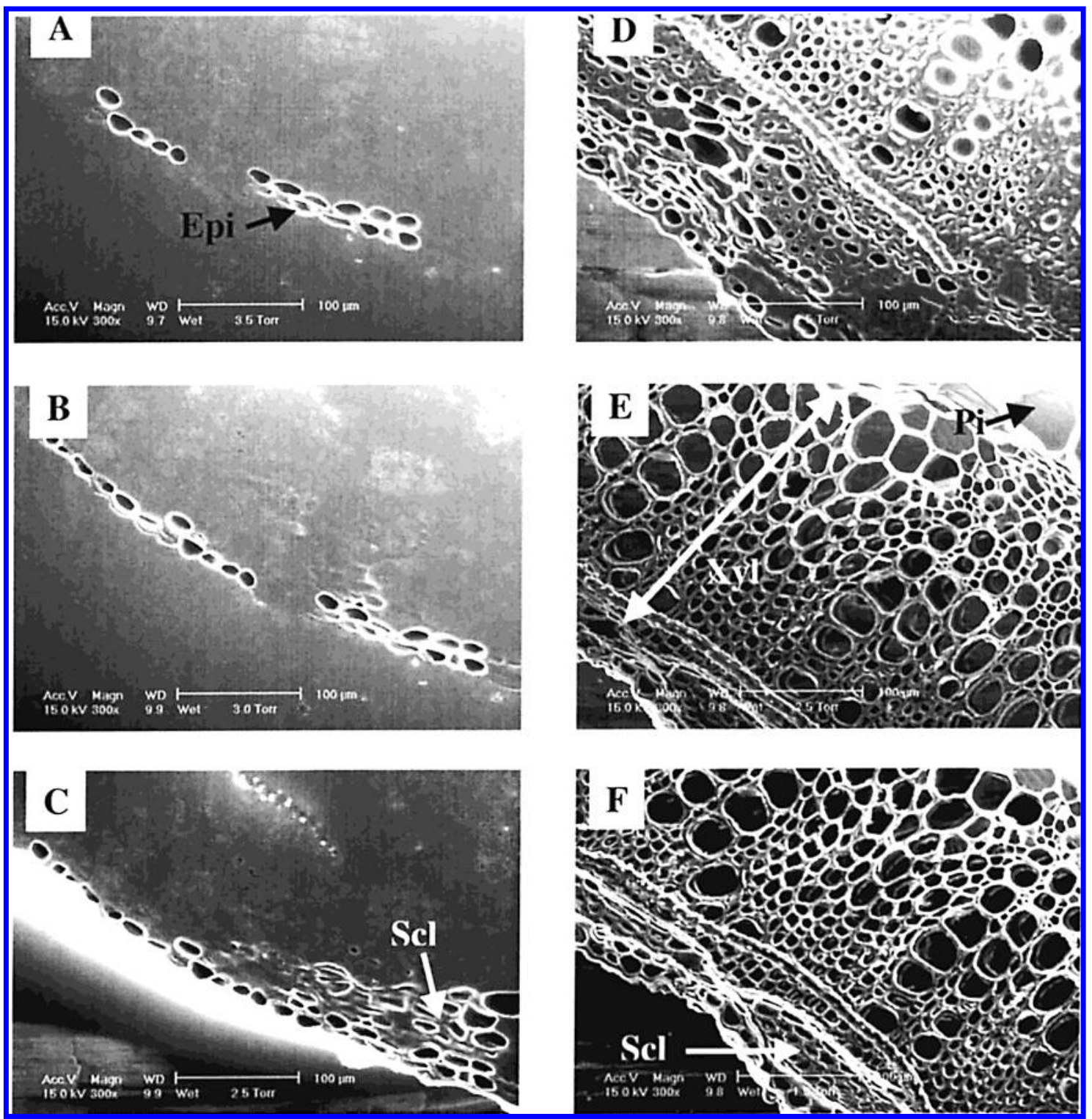

Figure 3. Transverse section of dehydrating alfalfa stem observed by ESEM at water vapor pressure varying from 10 Torr (A) to 1.5 Torr (F). Epi, epidermal cells; Scl, sclerenchyma; Xyl, xylem; Pi, pith.

fresh stems. Extractable neutral pectins (arabinans and arabinogalactans) could be thus affected by the heat treatment.

The successive fractionations of pectins (neutral and acid ones) indicated that the extraction of these polysaccharides was influenced by the oven-drying. The physical environment of these components and cross-linkages could be altered. Similar alterations have been recently found in the case of the industrial processing of alfalfa at high temperatures (Hamm et al., unpublished observations). These data indicate that the wall network involving pectin/hemicelluloses may be affected by drying, although the general composition of the cell walls is not modified.

Extracts of Hemicellulose Polymers. $\mathrm{NaOH}(1 \mathrm{~N})$ extracted $8.4-9.2 \%$ of the uronic acid and $13.5 \%$ of the neutral sugar from the initial CWRs (Tables 3 and 4). The relative compositions of neutral sugars indicated that there were similar alkalisoluble polysaccharides in fresh and dried alfalfa CWRs (Figure 2). Xylose accounted for $85 \%$ of the $1 \mathrm{~N} \mathrm{NaOH}$ soluble sugars; this reagent thus extracted $60 \%$ of the initial xylose in CWRs. These results confirm those of Halfield (28) for alkali fractionation. The concomitant occurrence of uronic acids indicated that glucuronoxylan extraction was not altered by heat treatment.

Hemicellulose polymers released by $4 \mathrm{~N} \mathrm{NaOH}$ contained less uronic acid than those released by $1 \mathrm{~N} \mathrm{NaOH}$ (Table 4). This reagent released heterogeneous classes of hemicelluloses, such as glucomannans and xyloglucans $(28,30)$. However, they were more readily extracted $(p<0.1)$ from dried stems. The hemicelluloses extracted with concentrated alkali seemed more accessible after heat treatment, and the xyloglucans differed presumably in their affinity for cellulose microfibrils after drying. Hydrogen bonds could be more readily broken in dehydrated alfalfa $(28,37)$. However, the relative compositions of neutral sugar in the solubilized fractions of fresh and 100 ${ }^{\circ} \mathrm{C}$-dried alfalfa were not significantly different (Figure 2). These data suggest that similar types of hemicelluloses were released despite the slightly greater yield from dried alfalfa CWRs.

Lignocellulosic Residues. Less mass was lost from heated stems $(48 \%)$ than from fresh stems $(52 \%)$ by cell wall fractionation. Neutral sugar represented $\sim 71 \%$ of the residual CWR in both fresh and dried alfalfa. Chemical fractionation 
did not completely extract all non-cellulose polysaccharides (Figure 2), as previously shown for secondary lignified cell walls $(14,30)$. The cell wall network involves various kinds of covalent and non-covalent cross-linkages between constituents, and lignin is said to hamper the complete removal of associated pectic compounds (28). As expected, most of the initial glucose $(86 \%)$ representing cellulose was not extracted. The amounts of residual lignin in fresh and dried alfalfa were similar. These values indicate that some lignin was lost during polysaccharide extraction. Vallet et al. (14) found a similar loss of lignin during the chemical fractionation of alfalfa cell walls. Less lignin was extracted from fresh alfalfa CWRs (45\%) than from the dried material $(51 \%)$. However, the monomer compositions of the residual uncondensed lignin fractions were not significantly different. The lower S/G molar ratio in residual CWR $(0.45-$ $0.48)$ than in the initial CWR $(0.52-0.58)$ indicates that the soluble lignin fraction corresponds to a syringyl-rich lignin fraction. Previous studies have shown that such lignin is mainly removed by alkali extraction of CWRs (14). Alkali removes lignin from grass by disrupting ester links (38), in contrast to legume lignin $(39,40)$. The present findings indicate that chemical reagents extract $50 \%$ of lignins once fractionation of the cell walls allowed removal of pectins. Therefore, alkalisoluble lignin may not be extracted because of its intimate pectin/hemicellulose association. Lignin is probably extracted as lignin-polysaccharide (LCC) complexes involving glucuronoxylan $(41,42)$.

ESEM. The stems of alfalfa were examined by ESEM as water was removed. The temperature of the analysis chamber was kept near $3{ }^{\circ} \mathrm{C}$ to obtain water pressure saturation $(100 \%$ relative humidity). Dynamic studies of stem tissue dehydration were done by gradually decreasing the vapor pressure from 10 to 1.9 Torr. Fully hydrated tissues were not clearly visible because of water masking; details became clearer as dehydration progressed.

Epidermal cells were first visible at $1-3{ }^{\circ} \mathrm{C}$ when the humidity of the specimen decreased from 80 to 60\% (Figure 3). Pieces of alfalfa stems contracted within a few seconds of water loss at $55 \%$ relative humidity, corresponding to 2.5 Torr (Figure 3). The outermost cells (poorly lignified) were crushed, whereas the lignified vessels and fibers (xylem) were not. The pith was the last tissue to become dehydrated. Water was lost from alfalfa tissues without disrupting the cell walls, in contrast to the observations of Thiel and Donald (43) on carrot tissues. Preliminary data were obtained for the cell and tissue integrity of dehydrating secondary wall-rich tissues. Further observations are needed to obtain a more comprehensive view of the temperature effect, which could not be examined in this study.

\section{ABBREVIATIONS USED}

CWR, cell wall residue; ESEM, environmental scanning electron microscopy; UA, uronic acid; Glu, glucose; Gal, galactose; Xyl, xylose; Man, mannose; Rha, rhamnose; Fu, fucose; Ara, arabinose; S, syringyl; G, guaiacyl.

\section{ACKNOWLEDGMENT}

Special thanks are due to Service d'Analyses Physico-Chimiques (F. Nadaud), University of Compiègne, for help in performing environmental scanning electronic microscopy.

\section{LITERATURE CITED}

(1) Dolz, J. Les techniques pour déshydrater. Perspect. Agric. 1977, $1-45$.
(2) Demarquilly, C.; Journet, M.; Beranger, C. Influence de la déshydratation et du mode de conditionnement sur la valeur alimentaire et l'utilisation des fourrages déshydratés. Fourrages 1973, 55, 217-235.

(3) Bailly, E. L'électricité atout de qualité en déshydratation de luzerne. Cah. Ind. Aliment. 1989, 5-10.

(4) Van Soest, P. Use of detergents in analysis of fibrous feeds. III. Study of effects of heating and drying on yield of fiber and lignin in forages. J. Assoc. Off. Anal. Chem. 1965, 48, 785-790.

(5) Abdalla, H.; Fox, D.; Van Soest, P. An evaluation of methods for preserving fresh forage samples before protein fraction determinations. J. Anim. Sci. 1988, 66, 2646-2649.

(6) Cone, J. W.; Vangelder, A. H.; Marvin, H. J. P. Influence of drying method and aging on chemical and physical properties and in vitro degradation characteristics of grass and maize samples. J. Agric. Sci. 1996, 126, 7-14.

(7) Kunzek, H.; Kabbert, R.; Gloyna, D. Aspects of material science in food processing: changes in plant cell walls of fruits and vegetables. Z. Lebensm. Unters. Forsch. A 1999, 208, 233-250.

(8) Plat, D.; Ben-Shalom, N.; Levi, A.; Reid, D.; Goldschmidt, E. Degradation of pectic substances in carrots by heat treatment. J. Agric. Food Chem. 1988, 36, 362-365.

(9) Stolle-Smits, T.; Beekhuizen, J. G.; Vandijk, C.; Voragen, A. G. J.; Recourt, K. Cell wall dissolution during industrial processing of green beans (Phaseolus vulgaris L). J. Agric. Food Chem. 1995, 43, 2480-2486.

(10) Martin-Cabrejas, M. A.; Jaime, L.; Karanja, C.; Downie, A. J.; Parker, M. L.; Lopez-Andreu, F. J.; Maina, G.; Esteban, R. M.; Smith, A. C.; Waldron, K. W. Modifications to physicochemical and nutritional properties of hard-to-cook beans (Phaseolus vulgaris L.) by extrusion cooking. J. Agric. Food Chem. 1999, 47, 1174-1182.

(11) Femenia, A.; Selvendran, R. R.; Ring, S. G.; Robertson, J. A. Effects of heat treatment and dehydration on properties of cauliflower fiber. J. Agric. Food Chem. 1999, 47, 728-732.

(12) Ballet, N. Etude de la digestibilité et de la valeur azotée de la luzerne déshydratée: Influence du stade de récolte et des traitements aux alcalis. Ph.D. thesis, Auvergne University, 1997.

(13) Fry, S. C. The Growing Plant Cell Wall: Chemical and Metabolic Analysis; Longman Scientific and Technical: Harlow, Essex, U.K., 1988.

(14) Vallet, C.; Lemaire, G.; Monties, B.; Chabbert, B. Cell wall fractionation of alfalfa stem in relation to internode development: biochemistry aspect. J. Agric. Food Chem. 1998, 46, $3458-3467$

(15) Zilliox, C.; Debeire, P. Hydrolysis of wheat straw by a thermostable endo-xylanase: Adsorption and kinetic studies. Enzyme Microb. Technol. 1998, 22, 58-63.

(16) Duchesne, I.; Daniel, G. The ultrastructure of wood fibre surfaces as shown by a variety of microscopical methods-a review. Nordic Pulp Paper Res. J. 1999, 14, 129-139.

(17) Blakeney, A. B.; Harris, P. J.; Henry, R. J.; Stone, B. A. A simple and rapid preparation of alditol acetates for monosaccharide analysis. Carbohvdr. Res. 1983, 113, 291-299.

(18) Seaman, J.; Moore, W.; Mitchell, R.; Millet, M. Techniques for determination of wood constituents by quantitative paper chromatography. Tappi J. 1954, 37, 336-343.

(19) Englyst, H. N.; Cummings, J. H. Simplified method for the measurement of total non starch polysaccharides by gas-liquid chromatography of constitent sugars as alditol acetates. Analvst 1984, 109, 937-942.

(20) Blumenkrantz, N.; Asboe-Hansen, G. New method for quantitative determination of uronic acids. Anal. Biochem. 1973, 54, 484-489.

(21) Kidby, D.; Davidson, D. A convenient ferricyanide estimation of reducing sugars in the nanomole range. Anal. Biochem. 1973 , $55,321-325$.

(22) Johnson, B. D.; Moore, W. E.; Zank, L. C. The spectrometric determination of lignin in small wood samples. Tappi J. 1961, 44, 793-798. 
(23) Iiyama, K.; Wallis, A. F. A. Determination of lignin in herbaceous plants by an improved acetyl bromide procedure. $\underline{J}$. Sci. Food Agric. 1990, 51, 145-161.

(24) Kurek, B.; Monties, B.; Odier, E. Dispersion of lignin in water: Characterization of the phenomenon and influence of lignin enzymic degradability. Holzforschung 1990, 44, 407-414.

(25) Lapierre, C.; Monties, B.; Rolando, R. Thioacidolysis of poplar lignins: identification of monomeric syringyl products and characterization of guaiacyl-syringyl rich fractions. Holzforschung 1986, 40, 113-119.

(26) Samain, E.; Debeire, P.; Debeire-Gosselin, M.; Touzel, J. Xylanase, xylanase Bacillus and application thereof. Brevet FR 9001 191, 1991.

(27) Debeire-Gosselin, M.; Loonis, M.; Samain, E.; Debeire, P. Purification and properties of a $22 \mathrm{kDa}$ endo-xylanase excreted by a new strain of thermophilic Bacillus. In Xylans and Xylanase; Visser, G. B. J., Voragen, A. G. J., Eds.; Elsevier Science: Amsterdam, The Netherlands, 1992; pp 463-466.

(28) Hatfield, R. D. Carbohydrate composition of alfalfa cell walls isolated from stem sections differing in maturity. J. Sci. Food Agric. 1992, 40, 424-430.

(29) Weightman, R.; Renard, C.; Thibault, J. Structure and properties of the polysaccharides from pea hulls. Part 1: Chemical extraction and fractionation of the polysaccharides. Carbohydr. Polvmers 1994, 24, 139-148.

(30) Titgemeyer, E. C.; Bourquin, L. D.; Fahey, G. C. J. Disappearance of cell wall monomeric components from fractions chemically isolated from alfalfa leaves and stems following In situ ruminal digestion. J. Sci. Food Agric. 1992, 58, 451-463.

(31) Bourquin, L.; Fahey, G. J. Ruminal digestion and glycosyl linkage patterns of cell wall components from leaf and stem fractions of alfalfa, orchardgrass, and wheat straw. J. Anim. Sci. 1994, 72, 1362-1374.

(32) Nordkvist, E.; Aman, P. Changes during growth in anatomical and chemical composition and in-vitro degradability of lucerne. J. Sci. Food Agric. 1986, 37, 1-7.

(33) Terashima, N.; Fukushima, K.; He, L.-F.; Takabe, K. Comprehensive model of the lignified plant cell wall. In Forage Cell Wall Structure and Digestibility; Jung, H. G., Buxton, D. R.,
Hatfield, R. D., Ralph, J., Eds.; ASA, CSSA, SSSA: Madison, WI, 1993; pp 247-270.

(34) Jung, H. G.; Deetz, D. A. Cell wall lignification and degradability. In Forage Cell Wall Structure and Digestibility; Jung, H. G., Buxton, D. R., Hatfield, R. D., Ralph, J., Eds.; ASA, CSSA, SSSA: Madison, WI, 1993; pp 315-341.

(35) Lequart, C.; Nuzillard, J. M.; Kurek, B.; Debeire, P. Hydrolysis of wheat bran and straw by an endo-xylanase: production and structural characterization of cinnamoyl-oligosaccharides. $\mathrm{Car}$ bohvdr. Res. 1999, 319, 102-111.

(36) Renard, C. M. G. C.; Voragen, A. G. J.; Thibault, J.-F.; Pilnik, W. Studies on apple protopectin: I-Extraction of insoluble pectin by chemical means. Carbohydr. Polvm. 1990, 12, 9-25.

(37) Valent, B. S.; Albersheim, P. The structure of plant cell walls. V: On the binding of xyloglucan to cellulose fibers. Plant Phvsiol. 1974, 54, 105-108.

(38) Scalbert, A.; Monties, B. Comparison of wheat straw lignin preparations. II. Straw lignin solubilisation in alkali. Holzforschung 1986, 40, 249-254.

(39) Canale, C. J.; Abrams, S. M.; Varga, G. A.; Muller, L. D. Alkalitreated orchardgrass and alfalfa: composition and in situ digestion of dry matter and cell wall components. J. Dairy Sci. 1990, 73, 2404-2412.

(40) Canale, C. J.; Varga, G. A.; Abrams, S. M. In situ disappearance of cell wall monosaccharides in alkali-treated orchardgrass and alfalfa. J. Dairv Sci. 1991, 74, 1018-1025.

(41) Musha, Y.; Goring, D. Klason and acid soluble lignin content of hardwoods. Wood Sci. 1974, 7, 133-134.

(42) Sawai, A.; Kondo, T.; Ara, S. Relationship between acid-soluble lignin content and hemicellulose degradability. Jpn. Grassl. Sci. 1984, 30, 165-169.

(43) Thiel, B. L.; Donald, A. M. In situ mechanical testing of fully hydrated carrots (Daucus carota) in the environmental SEM. Ann. Bot. 1998, 82, 727-73336.

Received for review October 1, 2001. Revised manuscript received January 10, 2002. Accepted January 14, 2002. This work was supported by a grant from Europol'Agro.

JF011294Q 